\title{
PENERAPAN MODEL PEMBELAJARAN CONCEPT SENTENCE UNTUK MENINGKATKAN KETERAMPILAN MENULIS TEKS EKSPLANASI FENOMENA ALAM MELALUI MEDIA AUDIO VISUAL PADA SISWA KELAS XI IPA 2 SMA KARTIKA XIII-1 AMBON
}

\author{
Selviana Mainassy
}

SMK Negeri 6 Kepulauan Tanimbar

e-mail: evimainassy@gmail.com

\begin{abstract}
Abstrak: Penelitian ini mendeskripsikan penerapan model pembelajaran Concept Sentence untuk meningkatkan keterampilan menulis teks eksplanasi fenomena alam melalui media audio visual pada siswa kelas XI IPA 2 SMA Kartika XIII-1 Ambon. PTK ini dilaksanakan melalui dua siklus. Hasil penelitian menyatakan bahwa model pembelajaran ini dapat merangsang siswa menyusun kalimatkalimat dengan beberapa kata kunci yang disediakan guru. Hasil observasi siklus 1, nilai rata-rata hasil belajar siswa adalah 70,94 dan ketuntasan belajar mencapai $68,75 \%$. Pada siklus 2 peningkatan nilai rata-rata hasil belajar siswa adalah 80,31 dengan ketuntasan belajar mencapai $87,5 \%$.
\end{abstract}

Kata Kunci: concept, sentence, media audio visual 


\title{
THE ASSEMBLING LEARNING MODEL OF CONCEPT SENTENCE TO INCREASE THE EKSPLANASI TEXT WRITING SKILL OF NATURE PHENOMENON THROUGH AUDIO VISUAL MEDIA ON STUDENTS IN CLASS XI IPA 2 SMA KARTIKA XIII-1 AMBON
}

\author{
Selviana Mainassy \\ SMK Negeri 6 Tanimbar Islands \\ e-mail: evimainassy@gmail.com
}

\begin{abstract}
This research describe the assembling learning model of Concept Sentence to increase the eksplanasi text writing skill of nature phenomenon through audio visual media on students in class XI IPA 2 SMA Kartika XIII-1 Ambon. This PTK is perform pass through two cycle. The result of research declare that this learning model can stimulate the students to arrange the sentences with some key word that being giving by teacher. Result observation of first cycle, the average grades of students is 70,94 and study completeness attain $68,75 \%$. On the second cycle the increasing of average grades of students is 80,31 with study completeness attain $87,5 \%$.
\end{abstract}

Keywords: concept, sentence, audio visual media 


\section{A. PENDAHULUAN}

Pendidikan adalah masalah serius yang harus diperhatikan. Hal ini menuntut partisipasi dari semua pihak. Keluarga merupakan tempat pendidikan awal peserta didik untuk belajar. Selanjutnya masyarakat tempat peserta didik bersosialisasi. Terlebih lagi dari dunia pendidikan sendiri yaitu guru sebagai tenaga pendidik.

Hal mendasar yang menjadi perhatian serius bagi pembelajaran bahasa Indonesia ialah keterampilan menulis sebuah teks. Dalam pembelajaran bahasa Indonesia di jenjang sekolah menengah atas selalu menggunakan teks. Setiap teks yang diajarkan, peserta didik diharapkan mampu mengidentifikasi dan menganalisis struktur dan kebahasaannya dan di akhir kompetensi dasarnya peserta didik dituntut dapat memproduksikan sebuah teks.

Keterampilan menulis merupakan salah satu dari empat keterampilan yang harus dikuasai siswa. Keterampilan ini diperoleh tidak secara instan tetapi harus dengan banyak berlatih. salah satu contoh ialah berlatih menulis teks dalam setiap pembelajaran bahasa Indonesia. Hal ini menuntut pemilihan model dan media pembelajaran yang tepat.

Dalam memproduksi sebuah teks, pemilihan media dan model pembelajaran sangat berperan penting. Media pembelajaran yang digunakan dalam mempelajari Kompetensi Dasar 3.4 memproduksi teks eksplanasi ialah media Audio Visual dengan model pembelajaran Discovery Learning. Berdasarkan data dari hasil pengamatan, siswa tertarik dengan media yang digunakan dan antusias dalam belajar. Namun hasil yang didapatkan dari nilai prasiklus tersebut masih di bawah KBM. KBM untuk kelas XI ialah 68.

Hasil pekerjaan siswa juga masih jauh dari apa yang diharapkan. Mereka hanya dapat menulis teks eksplanasi dalam dua paragraf dengan struktur yang belum lengkap. Aspek kebahasaan teks eksplanasi juga belum terlihat dalam hasil pekerjaan mereka. Ternyata para siswa mengalami kendala dalam menyusun kalimat-kalimat tersebut.

Berdasarkan uraian latar belakang, maka tujuan penelitian ini ialah "Mendeskripsikan penerapan model pembelajaran Concept Sentence untuk meningkatkan keterampilan menulis teks eksplanasi fenomena alam dengan menggunakan media audio visual pada siswa kelas XI IPA 2 SMA Kartika XIII-I"

Menulis merupakan suatu keterampilan berbahasa yang dipergunakan untuk berkomunikasi secara tidak langsung, tidak secara tatap muka dengan orang lain. Menulis pada dasarnya merupakan suatu kegiatan yang produktif dan ekspresif. Menulis ialah menurunkan atau melukiskan lambang-lambang grafik yang menggambarkan suatu bahasa yang dipahami oleh sesorang, sehingga orang lain dapat membaca lambang-lambang grafik tersebut kalau mereka memahami bahasa dan gambaran grafik itu. (Tarigan, 2008:22)

Menulis merupakan sebuah kegiatan menuangkan pikiran, gagasan, dan perasaan seorang yang diungkapkan dalam bahasa tulis. Menulis merupakan kegiatan untuk menyatakan pikiran dan perasaan dalam bentuk tulisan yang 
diharapkan dapat dipahami oleh pembaca dan berfungsi sebagai alat komunikasi secara tidak langsung. Kegiatan menulis sangat penting dalam pendidikan karena dapat membantu siswa melatih berpikir, mengungkapkan gagasan-gagasan dan memecahkan masalah.

Salah satu tujuan menulis ialah menggambarkan sesuatu, tulisan ini bertujuan agar pembaca seolah-olah ikut merasa, melihat, meraba, dan menikmati objek yang dilukiskan penulis. Tujuan penulisan ini dapat tergambar dalam teks eksplanasi. Teks eksplanasi merupakan sebuah karangan berisi penjelasan secara lengkap yang membahas suatu topik yang berhubungan dengan peristiwa atau fenomena. Fenomena tersebut dapat berupa fenomena alam seperti bencana alam. Bencana alam merupakan suatu peristiwa yang mengakibatkan dampak besar bagi populasi manusia. Bencana alam tersebut dapat berupa banjir, letusan gunung berapi, gempa bumi, tsunami, angin puting beliung, kebakaran liar, tanah longsor, badai salju, kekeringan, hujan angin, dan sebagainya.

Melalui model pembelajaran Concept Sentence dengan media audio visual akan memberikan kesempatan kepada para siswa untuk dapat menuangkan topik dan gagasan untuk menulis teks eksplanasi yang baik. Model Concept Sentence dapat membantu siswa dalam merumuskan topik dan gagasan-gagasan yang tepat dalam menulis sebuah teks eksplanasi Media audio visual dapat menarik perhatian siswa dalam pembelajaran

Media audio visual adalah merupakan media perantara atau penggunaan materi dan penyerapannya melalui pandangan dan pendengaran sehingga membangun kondisi yang dapat membuat siswa mampu memperoleh pengetahuan, keterampilan, atau sikap.

Yang dimaksud dengan media audio visual adalah media video yang disajikan dengan suara. Media tersebut dapat dimanfaatkan sebagai media pembelajaran untuk menulis teks ekplanasi. Bagian dari media yang digunakan dalam penelitian tersebut ialah sebagai berikut:

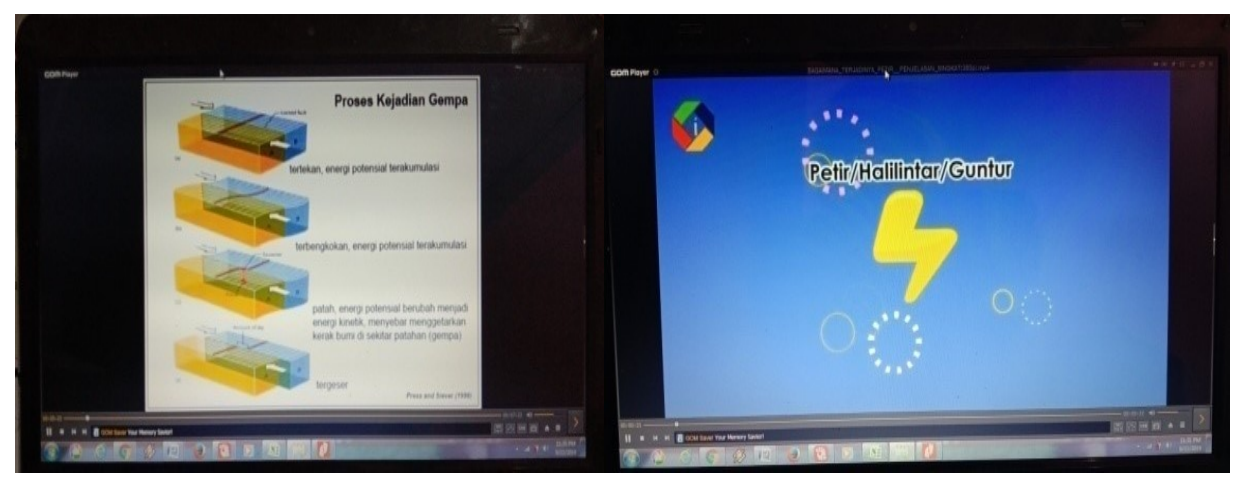


Penerapan Model Pembelajaran Concept Sentence untuk Meningkatkan Keterampilan Menulis Teks Eksplanasi Fenomena Alam Melalui Media Audio Visual pada Siswa Kelas XI IPA 2 SMA Kartika XIII-1 Ambon

\section{B. METODE PENELITIAN}

Penelitian ini merupakan penelitian tindakan (action research), karena penelitian dilakukan untuk memecahkan masalah pembelajaran di kelas. Penelitian ini juga termasuk penelitian deskriptif, sebab menggambarkan bagaimana peningkatan keterampilan siswa menulis sebuah teks eksplanasi dengan menggunakan model pembelajaran Concept Sentence dan bagaimana hasil yang diinginkan dapat dicapai.

Dalam penelitian ini peneliti bekerja sama dengan guru sejawat namun, kehadiran peneliti sebagai guru di kelas tidak diketahui oleh para siswa yang diteliti. Dengan cara ini diharapkan didapatkan data yang seobjektif mungkin demi kevalidan data yang diperlukan.

Penelitian ini menggunakan Penelitian Tindakan Kelas. Menurut Tim Pelatih Proyek PGSM, PTK adalah suatu bentuk kajian yang bersifat reflektif oleh pelaku tindakan yang dilakukan untuk meningkatkan kemantapan rasional dari tindakan mereka dalam melaksanakan tugas, memperdalam pemahaman terhadap tindakan-tindakan yang dilakukan itu, serta memperbaiki kondisi dimana praktek pembelajaran tersebut dilakukan. PTK adalah suatu bentuk kajian yang bersifat sistematis reflektif oleh pelaku tindakan untuk memperbaiki kondisi pembelajaran yang dilakukan. (dalam Mukhlis, 2003: 3).

Menurut Mukhlis (2003: 5) Adapun tujuan utama dari PTK adalah untuk memperbaiki/meningkatkan pratek pembelajaran secara berkesinambungan, sedangkan tujuan penyertaannya adalah menumbuhkan budaya meneliti di kalangan guru (Mukhlis, 2003: 5). Secara garis besar siklus PTK dibuat dalam empat tahap, yaitu: perencanaan, pelaksaan tindakan, observasi, dan refleksi. Keempat tahap tersebut dapat digambarkan sebagai berikut.

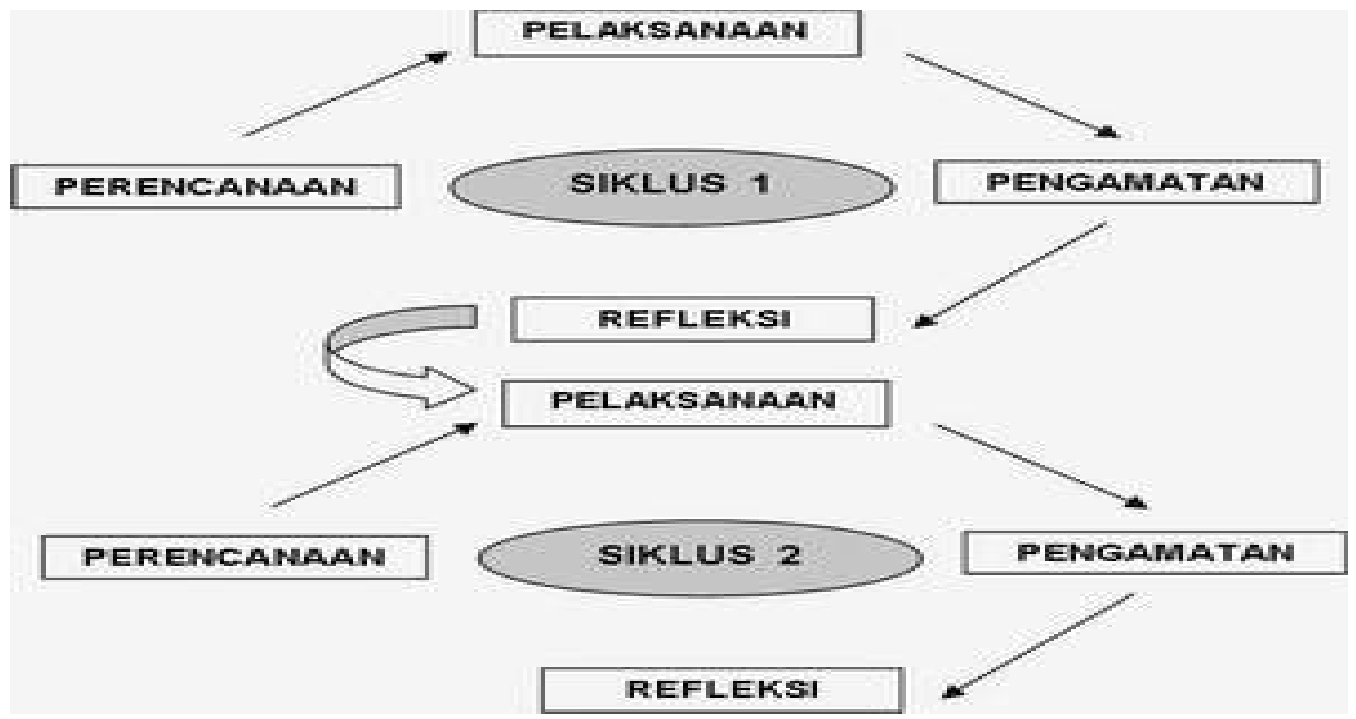

Gambar 4: Riset Aksi Model John Elliot

Subjek penelitian adalah siswa-siswa kelas XI IPA 2 SMA Negeri Kartika XIII-I. Jumlah siswa kelas ini 16 orang dengan perincian laki-laki 9 orang dan perempun 6 
orang. Data-data yang diperlukan dalam penelitian ini diperoleh melalui observasi aktivitas siswa dan guru, serta tes akhir.

Instrumen yang digunakan dalam penelitian ini terdiri dari:

1. Rencana Pelaksanaan Pembelajaran (RPP)

2. Naskah Soal

3. Lembar Observasi

4. Rubrik Penilaian Keterampilan

Untuk menganalisis data pada penelitian ini menggunakan teknik analisis deskriptif kualitatif, yaitu suatu metode penelitian yang bersifat menggambarkan kenyataan atau fakta sesuai dengan data yang diperoleh dengan tujuan untuk mengetahui hasil belajar yang dicapai siswa juga untuk memperoleh respon siswa terhadap kegiatan pembelajaran serta aktivitas siswa selama proses pembelajaran.

Untuk mengalisis peningkatan keberhasilan atau persentase keberhasilan siswa setelah proses belajar mengajar setiap putarannya dilakukan dengan cara memberikan evaluasi berupa soal tes tertulis pada setiap akhir pembelajaran.

Analisis ini dihitung dengan menggunakan statistik sederhana yaitu:

1. Untuk menilai tes akhir.

Peneliti melakukan penjumlahan nilai yang diperoleh siswa, yang selanjutnya dibagi dengan jumlah siswa yang ada di kelas tersebut sehingga diperoleh rata-rata tes formatif dapat dirumuskan:

$$
\bar{X}=\frac{\sum X}{\sum N}
$$

$$
\text { Dengan } \quad \begin{aligned}
: \bar{X} & =\text { Nilai rata-rata } \\
\Sigma \mathrm{X} & =\text { Jumlah semua nilai siswa } \\
\Sigma \mathrm{N} & =\text { Jumlah siswa }
\end{aligned}
$$

2. Untuk ketuntasan belajar

Ada dua kategori ketuntasan belajar yaitu secara perorangan dan secara klasikal. Berdasarkan petunjuk pelaksanaan belajar mengajar kurikulum 1994 (Depdikbud, 1994), yaitu seorang siswa telah tuntas belajar bila telah mencapai skor $65 \%$ atau nilai 65 , dan kelas disebut tuntas belajar bila di kelas tersebut terdapat $85 \%$ yang telah mencapai daya serap lebih dari atau sama dengan 65\%. Untuk menghitung persentase ketuntasan belajar digunakan rumus sebagai berikut:

$$
P=\frac{\sum \text { Siswa.yang.tuntas.belajar }}{\sum \text { Siswa }} \times 100 \%
$$

\section{PEMBAHASAN}

Berdasarkan hasil observasi pada siklus 1, menunjukkan bahwa pemahaman siswa terhadap materi pelajaran ada peningkatan karena guru sudah melakukan pembelajaran sesuai dengan langkah-langkah pada rencana pembelajaran. 
Penerapan Model Pembelajaran Concept Sentence untuk Meningkatkan Keterampilan Menulis Teks Eksplanasi Fenomena Alam Melalui Media Audio Visual pada Siswa Kelas XI IPA 2 SMA Kartika XIII-1 Ambon

Adapun kategori tingkat keberhasilan sebagai berikut:

\begin{tabular}{|c|c|c|}
\hline $\begin{array}{c}\text { Persentase tingkat } \\
\text { keberhasilan }\end{array}$ & Nilai huruf & Kategori \\
\hline $90-100 \%$ & A & Sangat baik \\
$79-89 \%$ & B & Baik \\
$68-78 \%$ & C & Cukup \\
$57-67 \%$ & D & Kurang \\
$<56 \%$ & E & Sangat kurang \\
\hline
\end{tabular}

Tabel 4.1 Kategori tingkat keberhasilan tindakan

HASIL REKAPAN NILAI SIKLUS 1

\begin{tabular}{|c|l|c|c|c|c|}
\hline NO & ASPEK & NILAI & RATA-RATA & \multicolumn{2}{|l|}{ KETERANGAN } \\
\hline 1 & ISI & 278 & 17.38 & 189 & \\
\hline 2 & ORGANISASI & 234 & 14.63 & $\mathrm{X}=$ & \\
\hline 3 & KOSAKATA & 230 & 14.38 & 16 & \\
\hline 4 & BAHASA & 204 & 12.75 & 70.94 & \\
\hline 5 & MEKANIK & 189 & 11.81 & & \\
\hline & JUMLAH & 1135 & 70.94 & & \\
\hline
\end{tabular}

Tabel 4.3 Rekapitulasi Nilai Siklus 1

Dari hasil rekap tabel tersebut diperoleh nilai rata-rata hasil belajar siswa adalah 70 , 94 dan ketuntasan belajar mencapai $68,75 \%$ atau ada 11 siswa dari 16 siswa sudah tuntas belajar. Hasil ini menunjukkan bahwa pada siklus I ketuntasan belajar secara klasikal telah mengalami peningkatan dari prasiklus.

HASIL BELAJAR SIKLUS 2

\begin{tabular}{|c|l|c|c|c|c|}
\hline NO & ASPEK & NILAI & RATA-RATA & \multicolumn{2}{|l|}{ KETERANGAN } \\
\hline 1 & ISI & 322 & 20.12 & 1285 & \\
\hline 2 & ORGANISASI & 261 & 16.31 & $\mathrm{X}=-$ & \\
\hline 3 & KOSAKATA & 258 & 16.12 & 16 & \\
\hline 4 & BAHASA & 229 & 14.31 & 81.30 & \\
\hline 5 & MEKANIK & 215 & 13.43 & & \\
\hline & JUMLAH & 1285 & 80.31 & & \\
\hline
\end{tabular}

Tabel 4.5 Rekapitulasi Nilai Siklus 2

Berdasarkan kedua tabel tersebut diperoleh nilai rata-rata tes akhir sebesar 80,31 dan dari 16 siswa, yang telah tuntas sebanyak 14 siswa dan 2 siswa belum mencapai ketuntasan belajar. Maka secara klasikal ketuntasan belajar yang telah tercapai sebesar 
87,5\% (termasuk kategori tuntas). Hasil pada siklus II ini mengalami peningkatan lebih dari siklus I. Adanya peningkatan hasil belajar pada siklus II ini dipengaruhi oleh adanya peningkatan kemampuan guru dalam menerapkan model pembelajaran Concept Sentence melalui media audio visual sehingga proses pembelajaran menjadi menyenangkan dan siswa dapat berpartisipasi aktif dalam proses pembelajaran. Peningkatan setiap siklus dapat dilihat pada grafik di bawah ini.

\section{Grafik Perbandingan Siklus}

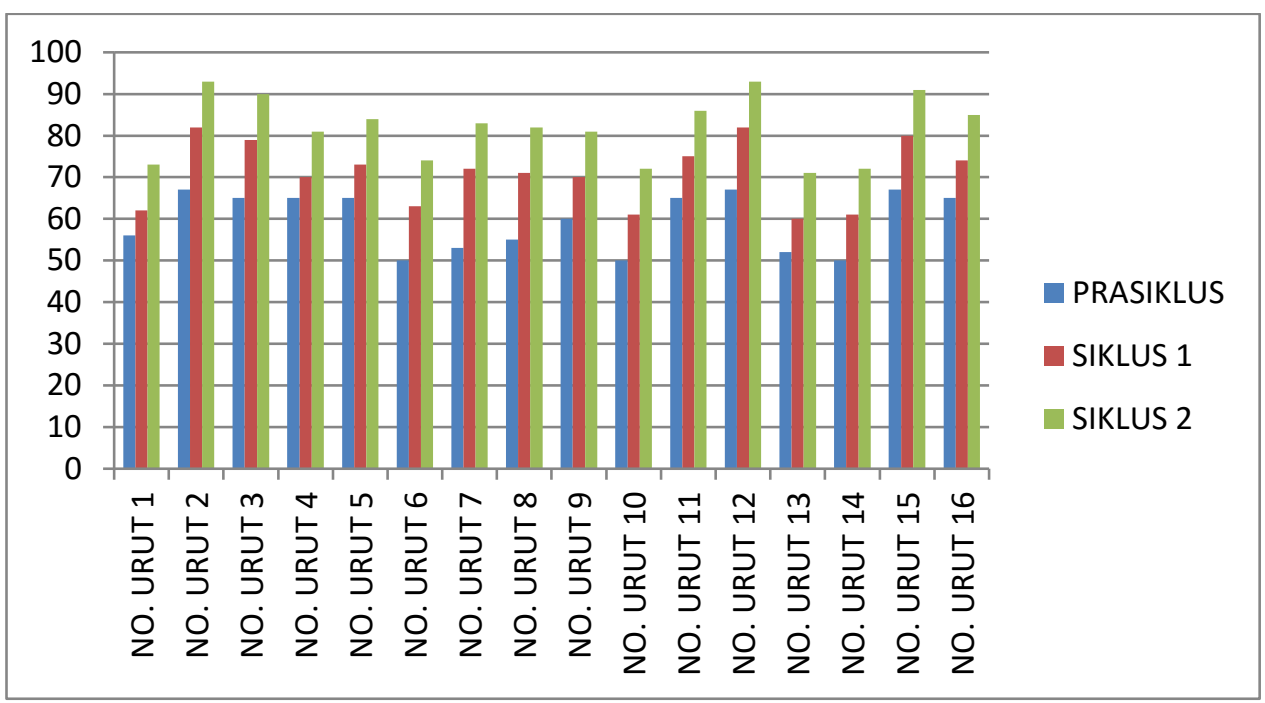

Grafik 4.1 Perbandingan Nilai Tes Setiap Siklus

Dari grafik di atas, dapat diketahui bahwa ada peningkatan dari setiap siklus. Ini menyatakan bahwa model pembelajaran Concept Sentence melalui media audio visual dapat diterapkan di sekolah sebagai alternatif untuk memperbaiki proses pembelajaran menjadi semakin baik.

Hal ini membuktikan bahwa keterampilan siswa dalam menyusun teks eksplanasi menjadi lebih meningkat. Siswa dapat menyusun teks eksplanasi dengan struktur yang tepat, pilihan kata yang digunakan juga sudah tepat, kesalahan penggunaan bahasa dan ejaan menjadi semakin kecil serta penggunaan tanda baca menjadi semakin baik.

Dari hasil kegiatan pembelajaran yang telah dilakukan selama dua siklus, dan berdasarkan seluruh pembahasan serta analisis yang telah dilakukan dapat disimpulkan sebagai berikut:

1. Pembelajaran dengan menggunakan model Concept Sentence melalui media audio visual dapat meningkatkan keterampilan siswa siswa dalam memproduksi teks eksplanasi fenomena alam yang ditandai dengan peningkatan ketuntasan belajar siswa dalam setiap siklus, yaitu siklus I (68,75\%), dan siklus II (87,5\%).

2. Penerapan model pembelajaran Concept Sentence mempunyai pengaruh positif, yaitu dapat meningkatkan keterampilan siswa dalam menulis teks eksplanasi fenomena alam melalui media audio visual 
Penerapan Model Pembelajaran Concept Sentence untuk Meningkatkan Keterampilan Menulis Teks Eksplanasi Fenomena Alam Melalui Media Audio Visual pada Siswa Kelas XI IPA 2 SMA Kartika XIII-1 Ambon

3. Model pembelajaran Concept Sentence melalui media audio visual dapat menarik minat siswa dalam menulis teks eskplanasi fenomena alam

\section{KESIMPULAN}

Dari hasil kegiatan pembelajaran yang telah dilakukan selama dua siklus, dan berdasarkan seluruh pembahasan serta analisis yang telah dilakukan dapat disimpulkan sebagai berikut:

1. Pembelajaran dengan menggunakan model Concept Sentence melalui media audio visual dapat meningkatkan keterampilan siswa siswa dalam memproduksi teks eksplanasi fenomena alam yang ditandai dengan peningkatan ketuntasan belajar siswa dalam setiap siklus, yaitu siklus I (68,75\%), dan siklus II (87,5\%).

2. Penerapan model pembelajaran Concept Sentence mempunyai pengaruh positif, yaitu dapat meningkatkan keterampilan siswa dalam menulis teks eksplanasi fenomena alam melalui media audio visual

3. Model pembelajaran Concept Sentence melalui media audio visual dapat menarik minat siswa dalam menulis teks eskplanasi fenomena alam.

\section{DAFTAR PUSTAKA}

Asik Belajar 9 (2019) Jenis-Jenis Media Pembelajaran. Dikutip 4 September 2019 dari Jenis-Jenis Media Pembelajaran: https://www.asikbelajar.com

Bahasa Indonesia Kelas XI PERMATA (Pembalajaran Siswa Meraih Prestasi) Kurikulum 2013 Cahaya Pustaka Edisi revisi 2017

Dosen Bahasa (2019) Kata Kerja Pasif. Dikutip 5 September 2019 dari Berikan Contoh Kata Kerja Aktif dan Kata Kerja Pasif: https://dosenbahasa.com

Fatkhan (2019 15 Maret) Pengertian Model Pembelajaran Concept Sentence. Dikutip 3 September 2019 dari Pengertian Model Pembelajaran Concept Sentence: https://www.seputarpengetahuan.co.id

Informasi Pendidikan (2014 Juni) Hakikat Media Pembelajaran. Dikutip 4 September 2019 dari Haikat Media Pembelajaran: http://www.informasi-pendidikan.com

Jadi Paham (2018 Oktober) Contoh Kalimat yang Menggunakan Kata Keterangan Waktu. Dikutip 5 September 2019 dari Kalimat yang Menggunakan Kata Keterangan Waktu: https://jadipaham.com

Ruang Guru (2019) Pengertian dan Struktur Teks Eksplanasi. Dikutip 5 September 2019 dari Pengertian dan Struktur Teks Eksplanasi: https://blog.ruangguru.com

Rosidi, Imron. 2009. Menulis ...Siapa Takut? Yogyakarta: Kanisius 
Penerapan Model Pembelajaran Concept Sentence untuk Meningkatkan Keterampilan Menulis Teks Eksplanasi Fenomena Alam Melalui Media Audio Visual pada Siswa Kelas XI IPA 2 SMA Kartika XIII-1 Ambon

Sarjanaku (2011 Maret) Media Audio Visual. Dikutip 4 September 2019 dari Media Audio Visual: http://www.sarjanaku.com 